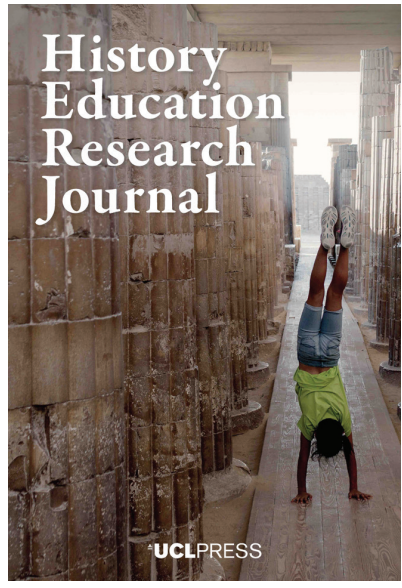

${ }^{\Perp}$ UCLPRESS

HISTORY EDUCATION RESEARCH JOURNAL

ISSN 2631-9713 (Online)

Journal homepage:

https://www.uclpress.co.uk/pages/history-educationresearch-journal

\title{
Collective memory and historical narratives: The African American civil rights movement
}

\author{
Richard Hughes (iD and Sarah Drake Brown (iD
}

\section{How to cite this article}

Hughes, R. and Drake Brown, S. (2021) 'Collective memory and historical narratives: The African American civil rights movement'. History Education Research Journal, 18 (2), 166-82. https://doi.org/10.14324/HERJ.18.2.03

Submission date: 15 January 2021

Acceptance date: 19 April 2021

Publication date: 19 October 2021

\section{Peer review}

This article has been peer-reviewed through the journal's standard double-blind peer review, where both the reviewers and authors are anonymised during review.

\section{Copyright}

(C) 2021 Hughes and Drake Brown. This is an open-access article distributed under the terms of the Creative Commons Attribution Licence (CC BY) 4.0 https://creativecommons.org/licenses/ by/4.0/, which permits unrestricted use, distribution and reproduction in any medium, provided the original authors and source are credited.

\section{Open access}

The History Education Research Journal is a peer-reviewed open-access journal. 


\title{
Collective memory and historical narratives: The African American civil rights movement
}

\author{
Richard Hughes* - Illinois State University, USA \\ Sarah Drake Brown - National Council for History Education, USA
}

\begin{abstract}
This study explores how undergraduates, as historical thinkers, learn to interact with history and construct their understanding of the past, and examines the role that primary and secondary sources play in narrative construction and revision. Using the African American civil rights movement as a content focus, participants used images to create initial narratives that reflected their understanding of the movement. Half the participants then read an essay on the movement written by a prominent historian, and the other half examined 18 primary sources that reflected the historian's interpretation of the movement. Participants then each created a second narrative, again selecting images to depict their understanding of the movement. The results of the study suggest that even as students work with primary sources, they need an effective narrative framework based on recent scholarship to forge powerful counter-narratives that transcend outdated interpretations and historical myths. In terms of teaching and learning about the lengthy struggle for racial justice in the United States, simply encouraging teachers and students to 'do history' and conduct their own online research is unlikely to change persistent narrative structures that continue to enable and excuse systemic racism.
\end{abstract}

Keywords: teacher candidates, narrative construction, race, collective memory, images

The civil rights movement circulates through American memory in forms and through channels that are at once powerful, dangerous, and hotly contested. (Hall, 2005: 1233)

\section{Introduction}

In the United States, powerful historical narratives often dominate the public's understanding of the past and contribute to a collective memory that reproduces knowledge about events and individuals deemed historically significant (Seixas, 2007; Seixas and Morton, 2013; VanSledright, 2011). The American collective memory has often been built around principles of expanding freedom and nation-building (Foner, 1999; Takaki, 1993), and an understanding that 'the United States was the only country in the world that began with perfection and aspired to progress' (Hofstadter, 1955: 36). While contemporary historians consistently offer challenges to this ever-present American narrative, Wertsch (2008: 142) has noted the power of 'specific narratives' and, especially, 'schematic narrative templates'. Schematic narrative templates run deep because such templates exist outside the bounds of conscious reflection and serve as 'very powerful coauthors' when individuals attempt to 'simply tell "what really 
happened"' (Wertsch, 2008: 142). Individuals might recite incorrect details within a narrative, but the continuing existence of basic elements of the narrative structure ensures its survival (Barton and Levstik, 2004). These basic elements rarely acknowledge problematic aspects of the nation's past (VanSledright, 2008). Instead, these narratives work to build a national community (Barton, 2012), and through the conscious use of pronouns that give students a sense of participation in the grand story (Barton, 2001; Barton and Levstik, 1998; Levstik, 2000), they serve as powerful cultural tools (Barton and Levstik, 2004; Salinas and Blevins, 2014; Wertsch, 1998).

Historical consciousness, or 'the area in which collective memory, the writing of history, and other modes of shaping images of the past in the public mind merge', provides a useful framework for the study of powerful narratives in the context of history education (Seixas, 2004: 10). In schools, collective memories can merge with or challenge formal school narratives, which are often articulated in curriculum materials. Through textbooks, nations often communicate 'cultural truths' using narrative templates that turn complicated histories with multiple layers into simplified stories of the past (Grever and Van der Vlies, 2017). Such narratives survive because of their ability to provide collective memory, because they are considered to be 'good stories' and because they inspire patriotism (Raphael, 2004, cited in Grever and Van der Vlies, 2017: 293). In school contexts, 'The teaching of history through narrative and story is thus commonplace but seldom suspect' (Salinas and Blevins, 2014: 36), provided that these stories do not undermine understood cultural truths.

Enduring narratives exist about the civil rights movement in the United States. In May 2019, hundreds of thousands of American high-school students answered an essay question on the Advanced Placement (AP) US history examination that asked them to 'Evaluate the extent to which ideas about democracy contributed to the African American Civil Rights Movement in the period from 1940-1970' (The College Board, 2019). The question on the AP examination, the closest thing that the United States has to a national curriculum in history, was simply the most recent evidence of the prominence of the civil rights movement, the persistence of narratives of progress, and the issue of race more broadly, in history education. In the United States, debates over Confederate monuments, reparations and historical roots of police brutality have increased in recent years. Americans have explored the centrality of race in new public museums, such as the National Museum of African American History and Culture in the nation's capital, and the National Memorial for Peace and Justice in Montgomery, Alabama. In classrooms, teachers and students have encountered innovative curriculum projects such as Teaching Hard History (Southern Poverty Law Center, n.d.) and The 1619 Project (New York Times Magazine, 2019), have read John Lewis's best-selling graphic novel trilogy, March, his memoir of being an activist in the civil rights movement (Lewis et al., 2013), and have watched the critically acclaimed and popular feature film Selma (2014). And in the streets, Americans have marched to address publicly contemporary police brutality and to insist that Black Lives Matter.

Furthermore, the American civil rights movement has enjoyed growing popularity in schools beyond the United States as countries look to history to help address growing issues of diversity, past and present. Students in New Zealand have found the history of the movement useful in understanding the experiences of indigenous peoples in their country (Frost, 2009). Lessons on racial segregation, non-violent protest and the rise of Black Power in the United States are a staple of the British secondary curriculum in modern world history. Rivalled only by attention given to the topic of slavery, the history of the American civil rights movement has contributed to larger curricular efforts in the UK, such as Abdul Mohamud and Robin Whitburn's (2016) 
Doing Justice to History: Transforming black history in secondary schools, debates about the role of empire in British history education, and the more recent emergence of The Black Curriculum (https://theblackcurriculum.com) to teach black British history and challenge the 'hegemonic assertion of white Western history' (Mohamud and Whitburn, 2016: 5; Moncrieffe, 2020).

The recent AP examination in US history was also indicative of another development dominating American history education: a movement to engage students in creating their own narratives - to 'do history' (Drake and Nelson, 2009; Lesh, 2011; Monte-Sano et al., 2014; Nokes, 2019; Seixas and Morton, 2013; Wineburg et al., 2011). In this context, The College Board revised the AP history examinations twice in recent years to promote and assess students' historical thinking skills. Reflected in part by popular curricula such as Reading Like a Historian (Stanford History Education Group, n.d.), and efforts such as Teaching with Primary Sources (Library of Congress, n.d.) and the College, Career, and Civic Life (C3) Framework (NCSS, 2013) to promote historical inquiry, the use of primary sources to teach the cognitive skills of historians has never been more popular. At the same time, numerous critiques of US history textbooks, such as James Loewen's (2018) immensely successful Lies My Teacher Told Me, have meant that history teachers, especially those trained in recent years, are increasingly committed to looking to primary sources and other resources to craft better historical narratives in the classroom. Such developments, however, raise questions about precisely how teachers craft historical narratives for instruction (Brown and Hughes, 2018).

Given a growing consensus about the need to broaden narrative structures in the teaching and learning of history, and especially in the context of the African American civil rights movement, this study examines the questions:

1) How do undergraduate students, as historical thinkers who interact with history, learn to construct their understanding of the past?

2) What role do primary and secondary sources play in shaping narratives, especially in terms of revising powerful master narratives and collective memory?

Considering the role of primary and secondary sources in shaping narratives necessitates an examination of the historiography of the civil rights movement.

\section{Historians' evolving interpretations: The civil rights movement}

The historiography of the civil rights movement is voluminous, and numerous historians have attempted the daunting task of synthesising the growing body of literature (Gaines, 2002; Lawson, 1991; Fairclough, 1990). Most relevant to this study is the important shift in recent decades away from older narratives that focused on a top-down approach to social change with an emphasis on biographies of leaders, especially Reverend Martin Luther King, Jr, and the relationship between prominent organisations, such as the National Association for the Advancement of Colored People (NAACP) and the Southern Christian Leadership Conference (SCLC), national politics centred on Washington DC, and legal changes in the South (Garrow, 1986; Oates, 1982; Branch, 1988). Focusing on what Bayard Rustin (1971: 111) identified as the 'classical phase' of the movement, framed by legal victories such as Brown $v$. Board of Education (1954) and the Voting Rights Act 1965, this celebratory narrative of a liberal consensus, limited mostly by black militancy, was associated with liberal historians and, later, with neo-conservatives interested in portraying American society as free from racial inequality (Hall, 2005: 1234; Matusow, 1984). As historian Jacquelyn 
Dowd Hall (2005: 1234) has argued, King is the traditional narrative's 'defining figure frozen in 1963' as he delivered his 'I have a dream' speech in Washington.

Fuelled by more radical historians sceptical of the ability of American post-war liberalism to achieve racial justice, revisionist interpretations have emphasised the agency of African Americans as the driving force for the movement, with studies of mass mobilisation (Morris, 1984), grass-roots organising (Carson, 1981; Payne, 1995), and a lengthy struggle for racial justice driven by relatively anonymous 'local people' on the community level (Dittmer, 1995; Chafe, 1980, Thornton, 2002). The newer histories of the movement have stressed its origins in the liberal-left coalitions and labour conflicts of the New Deal in the 1930s, as well as the importance of gender, women's activism, economic justice and black militancy in shaping a movement that was far more complex (Sullivan, 1996; Kelly, 1994; Crawford et al., 1990; Wright, 2013; Laurent and Wilson, 2018; Tyson, 1999; Jeffries, 2009; Joseph, 2006). The scope of more recent works has broadened to emphasise civil rights efforts and obstacles in the North, Midwest and West (Sugrue, 1996; Formisano, 1991; Biondi, 2002; Theoharis, 2018; Self, 2005), as well as the under-appreciated impact of global issues such as imperialism and the Cold War (Von Eschen, 1997; Dudziak, 2000). Finally, historians writing since the ascendancy of the New Right have contextualised the legacies and limits of the movement, and race relations in general, since 1968 within conservative politics and political realignment (Carter, 1996; Kousser, 1999; Kruse, 2005; Lawson, 2015).

A small but growing portion of historiography has focused on a topic of special importance to a study of teaching and learning: the relationship between the movement and memory. Often, as in the case of Julian Bond (2001) and Jenny Walker (2001), these analyses have focused on the important yet problematic role of the media in shaping narrow perceptions of the movement at the time and through historical narratives. Gary Daynes (1997: 51) has described different 'styles of commemoration' associated with efforts to remember King in Atlanta, with two approaches - 'memorial', focused on lobbying and fundraising, and 'tributary', focused on loyalty - often at odds with historians' commitment to historical evidence. For example, while the March on Washington remains central to the traditional narrative, Daynes (1997) points out that the event in 1963 was hardly representative of civil rights activism. The event's huge biracial crowd, national television audience, lack of violence and short length (one day) distort our perceptions of the gruelling and often unseen work of civil rights activists. Many accounts also diminish the importance of economic issues to the larger movement in referring to the event as simply the 'March on Washington', and omitting 'for Jobs and Freedom'. Above all, as Renee C. Romano and Leigh Raiford (2006) and other scholars have demonstrated, remembering the civil rights movement has been about struggle where politics, resources and identity - both collective and individual converge in ways to shape how Americans approach social problems today. As historian Jeanne Theoharis (2018: xiv) contends, how we conceptualise the history of the civil rights movement 'provides a shield for present-day action and inaction'.

Perhaps the most succinct and valuable argument for reinterpreting the movement came from historian Jacquelyn Dowd Hall (2005) in her Presidential Address to the Organization of American Historians entitled, 'The long civil rights movement and the political use of the past'. Hall (2005) criticised the master narrative of the movement as a narrow, misleading and politicised story that undermines the true legacies of a much longer and ongoing struggle for social justice. Rejecting the 'satisfying morality tale' that 'prevents one of the more remarkable mass movements in American history from speaking effectively to the challenges of our time', Hall (2005: $1235,1234)$ promoted a more complex narrative centred on national conflicts over 
race, class and gender - including determined activists, persistent opponents and contentious public policy - from the Great Depression through to the present day.

Hall's (2005: 1235) assertion that a revised narrative is 'harder to simplify, appropriate, and contain' has important implications for a crucial site in which history and memory collide: the history classroom. In addition to Loewen (2018), other scholars have criticised the impact of US history textbooks that prioritise the role of elites in forging the movement (Epstein, 2008), obscure the history of racial violence (Brown and Brown, 2010) and the crucial role of African American women activists, and commit a 'curriculum crime' in failing to incorporate issues after 1965, such as urban unrest and the positive contributions of the Black Power movement (Sanchez, 2016). Much of the criticism focuses on the misleadingly moderate image of King, often juxtaposed with Malcolm X, as a proxy for the entire movement, which ignores King's 'scathing critiques of American capitalism' and, after 1967, the American war in Vietnam (Alridge, 2006: 677). These critiques mainly emphasise content that is not included in textbooks, and focus on misrepresentations. Analysis of narrative structures within textbooks is also needed (Vanhulle, 2009), as is consideration of why specific content is included (Grever and Van der Vlies, 2017).

Curricula outside the United States have not fared much better. Scholars in the UK have lamented a history curriculum that leaves students profoundly 'ignorant about British imperial and colonial history' (Heath, 2018: n.p.), and which provides a simplistic account of the American civil rights movement (Ward and Hunt, 2020). The results are growing efforts to promote inquiry-based instruction in black British history that challenges older narratives and 'interrupt[s] the psyches of students and teachers' (Mohamud and Whitburn, 2016: 12). In part in response to the global Black Lives Matter movement, British educators have called for 'repositioning' history education (Moncrieffe and Harris, 2020) via the use of the online resource The Black Curriculum (https://theblackcurriculum.com) to decolonise classroom learning and address the role of white privilege, both in schools and in wider society. Such efforts on both sides of the Atlantic illustrate Terrie Epstein's (2008) argument that the intersection of racial identity and historical narratives in classrooms has profound implications for society's ability to understand race, inequality and the challenges of a pluralistic democracy.

As history teachers attempt to craft a coherent story for students by selecting and arranging topics, they draw upon forms of knowledge about history as a discipline that are specific to teaching history (Monte-Sano and Budano, 2013; Shulman, 1986). In world history (Bain and Harris, 2009; Harris and Bain, 2011) and in United States history (Wineburg and Wilson, 2001), researchers have noted distinct differences between novice and experienced teachers, and teachers who have disciplinary expertise when it comes to making choices about how to frame narratives. Recent movements emphasise the importance of teachers engaging students in 'doing history' (Drake and Nelson, 2009; Lesh, 2011; Monte-Sano et al., 2014; Nokes, 2019; Seixas and Morton, 2013; Wineburg et al., 2011), and emphasise historical thinking rather than the telling of a master narrative. The idea of narrative power has not necessarily diminished, however; rather, teachers are to teach students how to craft their own narratives. Yet, pre-service and experienced teachers continue to struggle as they consider how to offer alternative histories to dominant stories, and they often seek to adhere to a positive image of the past, even as they attempt to revise this history (Levstik, 2000; Swalwell et al., 2015). Barton (2012) has called for expanding the range of sources available to students in schools in order to complicate their understanding of narratives of freedom and progress. In this context, we devised a study that addressed specifically the use of primary sources and the role that secondary sources might play in shaping narratives, especially in terms of revising powerful master narratives and collective memory. 


\section{Setting and participants}

This research used a case study design (Yin, 2003) bound by definition and context (Miles and Huberman, 1994). Participants included 17 undergraduate history majors, mostly sophomores and juniors, who had completed an average of eight or nine college history courses, including surveys in United States history. The students (12 males and 5 females) were also teacher candidates in a secondary history education programme in a large Midwestern university and, with the exception of one Latinx student, all were white. The participants enrolled in an upper-level United States history special topics course, The United States in the Twentieth Century: Thinking and Learning About the American Past, offered during the spring 2015 semester. According to the syllabus, the course addressed 'key issues in twentieth century American history while also exploring explicitly how historians think, teach, and learn about history'. One of the authors was the instructor of the course.

Multiple assessments in the class focused on the constructed nature of history and the development of narratives. In the assessment considered here, students were first asked to use photographs or other images to create and defend a historical narrative of the African American civil rights movement (see Box 1). The initial assignment restricted the students' research to the internet and a chapter in United States History: Reconstruction to the present (Lapsansky-Werner et al., 2008), a widely used high-school US history textbook, modified to exclude all images and captions. Students also provided a brief rationale for their choices. They were given only 45 minutes to complete the task.

A week later, students were divided randomly into two groups (A and B). They were given specific instructions, which differed by group, to complete an additional written assignment at home (see Box 2). Of the 17 students in the class, 16 completed this second assignment, with 7 students in Group A completing the task and 9 students in Group B completing the task. Students in Group A read Hall's (2005) essay on the 'Long civil rights movement' in The Journal of American History. In contrast, students in Group B read a packet of 18 primary sources (see Box 3). These sources, which did not include photographs or other images, were chosen because they reflected Hall's (2005) revisionist interpretation that broadens the civil rights movement chronologically and geographically, and sees it as a struggle deeply tied to efforts to achieve racial, gender and economic justice. Mirroring a central argument in Hall's essay, the sources depicted a movement that started as early as the New Deal in the 1930s, included the ongoing struggle for racial justice after 1968, and portrayed racism as 'institutionalized patterns of exploitation, segregation, and discrimination' throughout the nation (Hall, 2005: 1239).

\section{Box 1: Assignment to create the students' initial narratives (all students)}

Task: Select 10 images that create a valuable historical narrative of the African American civil rights movement. Next to the image or a description of the image, you will need to explain in a few sentences why you chose to include it in your narrative. Why is the image valuable in terms of learning about the movement? Why did you choose it to be part of your short list of essential images?

You can use the following resources to craft your individual narrative on the movement:

- Scan of chapter in a typical high-school US history textbook, United States History: Reconstruction to the present (Lapsansky-Werner et al., 2008)

- Google

- Your understanding of the historical topic. 


\section{Box 2: Assignments to create students' revised narratives}

\section{Part I: A revision of your earlier narrative}

Select 10 images that create a valuable historical narrative of the African American civil rights movement. Next to the image or a description of the image, you will need to explain in a few sentences why you chose to include the image in your narrative. Why is the image valuable in terms of learning about the movement? Why did you choose the image to be part of your short list of essential images?

You can use the following four resources to recreate your individual narrative on the movement.

\section{Resources offered to Group A:}

- Scan of chapter in a typical high-school US history textbook, United States History: Reconstruction to the present (Lapsansky-Werner et al., 2008)

- Google

- Your understanding of the historical topic

- Essay by Jacquelyn Dowd Hall, 'The long civil rights movement and the political uses of the past' (Journal of American History, 2005), attached to this assignment in ReggieNet.

\section{Part II: Final reflection}

In a 2-3 page, double-spaced, typed essay, describe the impact of this assignment on you as both a historian and a history teacher. Some questions to address are: What are the implications of your new narrative for United States history? How would you compare your preliminary narrative of the civil rights movement with your revised narrative? How would you describe the experience of creating and recreating meaningful historical narratives? As a teacher, how would this assignment impact your work and/or the experiences of your future students? Please use specific examples from your resources to illustrate your points.

\section{Box 3: The collection of primary sources given to students in Group B}

1. Flyer for Tobacco Workers' Strike, South Carolina, 1945

2. Martin Luther King speech, 'Beyond Vietnam', 1967

3. March on Washington for Jobs and Freedom, pamphlet, 1963

4. Lyrics for song from labour and civil rights movement, 'Which side are you on?'

5. Federal Bureau of Investigation (FBI) letter to Martin Luther King, 1964

6. Employment advertisements depicting racial and gender discrimination from The Atlanta Constitution newspaper, 1960

7. Double V Campaign during the Second World War, Pittsburgh Courier, 1942

8. Letter from Massachusetts Black Caucus on race and antibusing moving in Boston, 1974

9. Newspaper article on the violent reaction by white opponents of the movement in Chicago, 'Rights hecklers burn cars', Chicago Tribune, August 1966

10. Poem expressing link between white racism and anti-tax movement in Atlanta, 1963

11. Kevin Phillips's essay on the South and the New Right, 'The emerging Republican majority', New York Times, 1969

12. Memoir 'Negro in the CCC', 1935

13. State maps of US presidential elections, 1944-84

14. Housing and 'racial compatibility' in real estate, Federal Housing Association's Manual, 1938

15. Excerpt from Civil Rights Act 1964 that includes reference to 'sex'

16. Excerpt from Ronald Reagan's campaign speech in Neshoba County, Mississippi, 1980

17. Excerpt from Joseph Kamp, Communist Carpetbaggers in Operation Dixie, 1946

18. Oral history interview with white opponent of school busing in Boston, 2005. 
To summarise, students assigned randomly to Group A read a secondary source, an essay penned by a prominent historian. Students assigned randomly to Group B examined primary sources that the instructor selected, which were chosen because they aligned with a central argument in the historian's essay. After reading their assignment materials, students in both Groups A and B were instructed to craft narratives by again selecting a set of 10 images to tell a story of the movement.

Students completed all work individually. Finally, students in both groups provided a rationale for their revised collection of photographs on the movement and, as instructed in Part II of the assignment, wrote a final reflection which described the impact of the assignment on their role as a historian and an emerging history teacher.

\section{Data and analysis: Initial narratives}

Students' assessments consisted of images and accompanying written explanations of their selections. Researchers recorded the images that students chose, and engaged in content analysis of their written work. Given the nature of the assignment, few specific themes emerged in the written portion of the assignment; rather, specific details and a rationale for the decisions made were noted. While the 17 teacher candidates who submitted the initial narrative assignment had completed eight or nine history courses at the college level, a review of their transcripts suggested that they entered the class with varied backgrounds in United States history. However, their narratives indicated a substantial consensus about the civil rights movement, as their choices reflected the traditional narrative of the movement in the South between 1954 and 1965. Photographs of Martin Luther King, Rosa Parks and often anonymous civil rights activists involved in direct action in southern locations such as Montgomery, Little Rock, Greensboro and Birmingham dominated their narratives, and a story of progress and expanding freedoms emerged consistently. One teacher candidate who misunderstood the directions to choose only primary sources even included a graphic of a timeline for the movement, entitled 'Civil rights progress: 1954-1968'. Of the 17 teacher candidates, 15 chose photographs of King at the 1963 March on Washington for Jobs and Freedom, while 10 of the narratives included various images of Rosa Parks. Only 6 included images from before 1954, such as photographs meant to symbolise the US Supreme Court ruling in Plessy v. Ferguson (1896). Other figures, such as Malcolm X or members of the Black Panthers, were included in 7 of the narratives. Only 2 of the 17 students referenced contemporary issues, such as the 2014 protests in Ferguson, Missouri and the Black Lives Matter movement. Just 3 students included overt references to gender, and a single teacher candidate in the group included images portraying the efforts of Native Americans and Latinos to achieve racial justice. Finally, even though the teacher candidates attended high school and college in the Midwest, 92 per cent of the total of 170 images portrayed the movement in the South, with no overt references to civil rights struggles in northern cities such as Chicago or Detroit.

The students on this course, similar to Americans surveyed by Wineburg and Monte-Sano (2008), crafted a remarkably consistent narrative centered on well-known figures. The 10 images selected by one student in the class reflected and illustrated this rather traditional approach:

1) Jim Crow water fountain

2) Brown v. Board of Education (1954)

3) African American student at Little Rock High School, 1957

4) Rosa Parks 
5) Martin Luther King and the Southern Christian Leadership Conference

6) Student Nonviolent Coordinating Committee and lunch counter sit-ins

7) King's 'I have a dream' speech in 1963

8) President Lyndon Johnson and the 1964 Civil Rights Act

9) March on Selma, 1965

10) President Johnson and the 1965 Voting Rights Act.

\section{Revised narrative findings}

\section{Group A}

The seven students who read Hall's (2005) essay on the 'Long civil rights movement' selected a new set of images that reflected a narrative about a struggle for racial justice that originated in the nineteenth century, and included more efforts since the 1960s, such as the battles over school busing and the Equal Rights Amendment, and recent debates about the Black Lives Matter movement and gay marriage. In addition to conventional images, these narratives included a portrait of anti-lynching activist Ida B. Wells from the nineteenth century, a map of the Great Migration of African Americans to the urban North starting in 1916, and a photograph of the Harlem Hellfighters, an all-black infantry unit from the First World War, as well as a graphic depicting the Double $V$ campaign during the Second World War to highlight, in the student's words, 'efforts of black Americans to use both domestic and foreign US policy to shape their arguments for civil rights'. Another narrative included a photograph portraying Southern white opponents to 'race mixing' that explained how the Cold War and anticommunism 'destroyed the postwar black-labor-left coalition' and 'strengthened the Republican party'.

In contrast to both their initial narratives and those narratives offered in most US history textbooks, students in Group A chose numerous images that linked race and labour as part of a broader, enduring activism that viewed economic justice as central to racial equality. Their revised narratives illustrated Hall's (2005: 1239) argument about the 'gordian knot that ties race to class and civil rights to workers' rights'. A student included a cartoon of the Federal Employment Practices Commission (FEPC), formed by President Franklin Roosevelt in 1941 to, according to the student, 'put racial discrimination on the national agenda for the first time since Reconstruction'. The same student included a photograph of labour leader A. Philip Randolph, while another student chose an image depicting the Taft-Hartley Act of 1947 as part of an argument about the challenges facing African American workers after the Second World War. Two more students referenced the central role of the US federal government in shaping the growth of a racially exclusive white suburbia in the post-war period. One narrative portrayed white Americans benefiting from a racist federal policy related to home mortgages, while another included a housing map of 1950 Atlanta depicting 'white flight'. Interestingly, one student referenced the 'racial tensions' in the North, while also quoting Hall (2005: 1246) about the links between civil rights and the efforts of unions to fight discrimination via 'universalistic social welfare policies'. However, this student was unable to pair these commentaries with images that actually depicted these important interpretations.

\section{Group B}

Despite access to 18 provocative primary sources that reflected the trajectory of a long civil rights movement, the nine students in Group B still chose images that relied heavily 
on the traditional narrative. About 85 per cent (77) of the total of 90 total images from the group illustrated events between 1954 and 1968, almost all of which portrayed the movement in the South. Eight of the nine students included images representing direct action protests in cities such as Montgomery, Greensboro and Birmingham. The Brown v. Board of Education US Supreme Court case was depicted in 11 images, with multiple students also selecting images of King, Rosa Parks, the Little Rock Nine, the Freedom Rides and the Civil Rights Act 1964. Images of Malcolm X, the Black Panthers and segregated Southern facilities such as bathrooms were each included in three narratives. One student inexplicably chose a photograph of black and white hands.

Even students who aimed to create a broader narrative struggled, as 13 additional images simply replicated one of the sources provided in the original set, such as the poster depicting labour unrest among tobacco workers (Box 3, Source 1), the article in the Chicago Tribune reporting racial violence in 1966 (Box 3, Source 9), and the letter associated with the Double V campaign in the Pittsburgh Courier during the Second World War (Box 3, Source 7). Other duplications involved the FBI letter to King (Box 3, Source 5), King's speech about Vietnam (Box 3, Source 2), the Civil Rights Act 1964 (Box 3, Source 15), and the anti-taxation poem from Atlanta (Box 3, Source 10). In these cases, the students submitted a broader narrative of the movement, but they provided no evidence that they were able or willing to locate and use new images to craft narratives that illustrated important issues such as the role of labour conflict, the relationship between civil rights, war and American foreign policy, or the complex role of the federal government and the rise of modern conservatism in shaping the movement. The narratives completely or largely avoided images associated with a number of events that often receive substantial coverage in US survey courses at the undergraduate level, such as the New Deal and the Great Depression, the political realignment of the Republican Party in the South after 1968, and the persistent challenges of racial discrimination and segregation in the urban North.

Sometimes the inclusion did not necessarily mean that students understood the implications of such evidence for revising older narratives. Three of the four teacher candidates who used the 1964 Civil Rights Act failed to mention its later importance in terms of gender equality (even though the included excerpt made a specific reference to sex), and only three of the seven teacher candidates who referenced the March on Washington for Jobs and Freedom discussed the emphasis that the event placed on jobs and economic justice. In a particularly revealing example, one student included an instructive photograph from the 1963 event filled with placards that declared, 'We Demand An FEPC Law Now', 'AFL-CIO For Full Employment' and 'We March for Jobs for All Now!', with only vague commentary about 'equal rights' and the fact that whites were involved in the march as well. The images associated with the conventional narrative of the movement, plus duplications from the primary source packet, meant that only about 12 per cent of the images provided by the students in Group B represented new selections that reflected a more revisionist interpretation of the movement. These images included photographs of such figures as A. Philip Randolph, Bayard Rustin, Richard Nixon and J. Edgar Hoover, as well as references to abolitionism, the 13th Amendment, race riots in 1919, and 2014 protests about the police shooting in Ferguson, Missouri.

\section{Discussion}

The results of the study suggest that secondary sources such as Hall's (2005) provocative essay on the long civil rights movement are far more effective than primary sources 
for encouraging emerging teacher candidates both to revise conventional historical narratives and perhaps to confront their own often unexamined role in creating narratives. As history textbooks garner increased criticism, and history education continues to embrace the teaching of historical thinking through primary sources, teacher candidates may be ill-equipped to select meaningful primary source evidence. Emerging teachers may need additional support in understanding the implications of narratives and interrogating primary sources, especially as undergraduate survey courses, the college courses closest to high-school history classes, often involve the fewest opportunities to analyse and employ primary source evidence. For example, many of the participants in the study who read Hall's (2005) essay (Group A) commented on how the secondary source 'opened my eyes' and challenged their naivety. These teacher candidates reflected on how teachers and students are 'constantly evaluating and re-evaluating' their perspectives about the past. In contrast, the teacher candidates who worked with primary sources (Group B) largely commented on their lack of knowledge. They perceived narratives as static and either accurate or inaccurate, but, without a framework to guide their thinking, the primary sources they read were not enough. For these students, the sources allowed them to 'assess the holes' in their background knowledge, but their engagement with the sources then stalled.

From prolific photographs in newspapers and magazines in the 1950s, to contemporary textbooks, images have long been central to our understanding of the civil rights movement. In fact, research suggests that images are crucial to the way in which many people engage with the past. In the 1990s, historians David Thelen and Roy Rosenzweig conducted a study of the relationship between Americans and the past. Despite frequent criticisms of Americans as historically illiterate, they described the 'widespread nature of American engagement with the past' (Rosenzweig, 2000: 264). However, the degree of engagement varied a great deal, with significant implications for this study. While Americans generally felt 'unconnected' from history while 'studying history in school', over 91 per cent of those surveyed identified looking at historical photographs with family, and almost as many reported interacting with history via films and television programmes in the previous 12 months (Rosenzweig, 2000: 265). In our study, conducted two decades later, the teacher candidates reinforced these experiences, as every participant reported that they had watched films or television programmes related to history, looked at historical photographs, and, perhaps reflecting the ubiquitous role of phone cameras in American life, taken photographs to preserve memories. They also agreed with Americans surveyed earlier that history museums and personal accounts - two experiences often dominated by photographic evidence - were more trustworthy as sources than high-school teachers, college professors, books, or films and television. Although the college history majors, not surprisingly, reported far more frequent engagement with history through books than Americans in general, images of the past still dominated how they, as emerging teachers, experienced historical narratives.

When surveyed about how they, as future teachers armed with only a textbook and a laptop, crafted their initial narratives of the civil rights movement, the students estimated how much of the 45 minutes allotted for this assignment they spent on various resources. Taken as a whole, the class reportedly spent 44 per cent of the time on Google Images, 17 per cent thinking about their past high-school and college history courses, 15 per cent looking at the high-school history textbook, and 12 per cent reading text sources found via Google. They spent about 6 per cent of the time thinking about films and other forms of popular culture, and the rest of the 
time on miscellaneous sources such as Wikipedia and personal experiences of travel or museums.

This self-reported reliance on images on the internet (for the crafting of their initial narratives) allowed the students to find and use photographs that, in part due to origins in the mass media of the mid twentieth century, simply reinforced the misleading and distorted narrative that historians have challenged for decades. While the digital age may mean seemingly unlimited access to data, it might not help teachers craft meaningful counter-narratives, and it might, in fact, have limited them. The students' searches for this study yielded photographs that largely mirrored the troubling limitations of mainstream textbooks. Their subsequent initial narratives differed little from the images that had been removed from the secondary US history textbook that they used, which relied on an impressive 40 images in fewer pages, yet only included 3 photographs that challenged the classic interpretation of the movement. For Group B, their revised narratives reflected a similarly limited and narrow understanding of the movement. It is likely that teachers who are capable of designing instruction that reflects the weight of recent scholarship need more support in finding and employing digital evidence.

While images may be crucial to the historical consciousness (Seixas, 2004) of both teachers and students, it is also possible for emerging teachers, regardless of flawed curriculum materials, and even limited academic background, to examine and revise existing historical narratives. However, this study underscores the role of the media, and American popular and political culture, in hindering the ability of teachers to craft meaningful counter-narratives. Despite the dramatic rise in calls for a racial reckoning in the United States, and the growing commitment of educators to develop culturally competent teachers, to teach hard history and to promote social justice, traditional narratives - what one historian refers to as a 'palatable ... fable' (Theoharis, 2018: 141, 211) - still dominate history classrooms. Unlike in previous eras, the problem is not that African American history is excluded from the curriculum; it is that it is often conceptualised and taught in a way that prevents students from understanding the long struggle for racial justice in a way that addresses the structural racism, white privilege, gender discrimination, and crucial relationship between American capitalism and social inequality that continue to shape so much of the lives of teachers and students today. For example, the fact that few teacher candidates even attempted to use historical evidence associated with the rise of a politically conservative counter-revolution after 1968 leaves their future students ill-equipped to understand the complex ways in which race continues to inform American politics. The master narrative frames the movement as successful by 1965, and therefore largely divorced from the contemporary debates over race that dominate American culture during their lifetimes. In this sense, teachers who continue to frame the civil rights movement in narrow terms are perhaps inadvertently complicit in opposing racial change. And their students, especially students of colour, know it. The result, as Terrie Epstein (2008: 9) argues, is that 'millions of young people leave the public schools knowing a nationalistic perspective but not believing it, while those who accept it have no framework for understanding racism and other forms of inequality today'.

If remembrance is, as Hall (2005: 1233) suggests, 'always a form of forgetting', then history classrooms are the wellspring for our society's collective amnesia. How do we prepare teachers who understand the central role of analysis and reinterpretation, what Hall (2005: 1263) describes as 'novel forms of storytelling', as being not just the craft of historians, but also crucial to the daily efforts of teachers and their students? Although photographs remain accessible and valuable primary sources for modern 
history, can historians and history teachers rely on them to portray the sort of complex and often subtle ways in which structural racism and racial identity have shaped history? If historical narratives are inevitably arguments and, as John A. Arnold (2000: 122) has argued, 'arguments present the opportunity for change', how can teachers best interact with historical evidence to empower students to confront the past and imagine a more just and equitable future?

Our study of how emerging history teachers attempt to reframe their understanding of the civil rights movement underscores the importance of an effective narrative framework from which to inform the selection of meaningful primary source evidence. Informed by Hall's (2005) provocative notion of a long civil rights movement that reflects both recent scholarship and the complexity of race in contemporary America, students in Group A were far more likely to forge powerful counter-narratives for the classroom. In contrast, the experience of students in Group B suggests that teachers, despite a commitment to use primary sources to teach both historical content and skills, often struggle to create lessons that transcend outdated interpretations and historical myths without the use of rich narratives tied to the evolving work of historians. In terms of teaching and learning about the lengthy struggle for racial justice in the United States, simply encouraging teachers and students to 'do history' and conduct their own online research is not going to change persistent narrative structures that continue to enable and excuse systemic racism. This 2015 study, conducted after the shooting of Trayvon Martin in Florida in 2012, the founding of the Black Lives Matter movement in 2013, and the shooting of Michael Brown in Ferguson, Missouri in 2014, speaks to the enduring power of narratives and collective memory. Recent events in American society, specifically the increased visibility of the Black Lives Matter movement in 2020 and attention to systemic racism in the United States, remind us of the necessity of constantly revisiting students' construction of narratives, and the power that collective memory holds over our understanding of the past.

Darryl Pinckney, author of numerous books and essays on African American history and culture, recently reflected on the different experiences of encountering the history of the civil rights movement in books and via the successful feature film Selma. Pinckney (2015: n.p.) concluded that, 'although reading in the U.S. is a minority activity, the book is still the only medium in which you can make a complicated argument. For the black experience', he explained, 'the word is still chief witness'. The challenge remains how to prepare history teachers as another kind of witness, capable of crafting the type of classrooms and professional lives that nurture the complicated arguments that students and other citizens need to engage the past and make sense of the present.

\section{Research ethics statement}

The authors declare that research ethics approval for this article was provided by the Institutional Review Board, Illinois State University, Protocol 2014-0414.

\section{Conflicts of interest statement}

The authors declare no conflict of interest with this work.

\section{Notes on the contributors}

Richard Hughes is Associate Professor of History at Illinois State University, USA, where he teaches courses in US history and history education as part of the secondary 
teacher education programme. He serves as Assistant Editor for Teaching History: A Journal of Methods, and is an officer in the International Society for the Scholarship of Teaching and Learning in History. His research interests range from race in modern US history to the evolving disciplinary understandings of history teachers.

Sarah Drake Brown is Associate Director of the National Council for History Education (USA). She is Editor of Teaching History: A Journal of Methods, and her research focuses on teacher candidates' developing historical understandings and use of assessment, and on history teachers' professional learning.

\section{References}

Alridge, D. (2006) 'The limits of master narratives in history textbooks: An analysis of representations of Martin Luther King, Jr'. Teachers College Record, 108 (4), 662-86. Accessed 13 July 2021. www.academia.edu/10229933/The_Limits_of_Master_Narratives_in_History_Textbooks_An_ Analysis_of_Representations_of_Martin_Luther_King_Jr.

Arnold, J.A. (2000) History: A very short introduction. New York: Oxford University Press.

Bain, R. and Harris, L.M. (2009) 'A most pressing challenge: Preparing teachers of world history'. Perspectives on History, 47 (7), 33-6. Accessed 2 August 2021. www.historians.org/publicationsand-directories/perspectives-on-history/october-2009/a-most-pressing-challenge-preparingteachers-of-world-history.

Barton, K. (2001) "“You'd be wanting to know about the past": Social contexts of children's historical understanding in Northern Ireland and the United States'. Comparative Education, 37 (1), 89-106. https://doi.org/10.1080/03050060020020444.

Barton, K. (2012) 'School history as a resource for constructing identities: Implications of research from the United States, Northern Ireland, and New Zealand'. In M. Carretero, M. Asensio and M. Rodriguez-Moneo (eds), History Education and the Construction of National Identities. Charlotte, NC: Information Age, 94-107.

Barton, K. and Levstik, L. (1998) '“It wasn't a good part of history": Ambiguity and identity in middle grade students' judgments of historical significance'. Teachers College Record, 99 (3), 478-513.

Barton, K. and Levstik, L. (2004) Teaching History for the Common Good. Mahwah, NJ: Lawrence Erlbaum Associates.

Biondi, M. (2002) 'To Stand and Fight': The struggle for civil rights in postwar New York City. Cambridge: Harvard University Press.

Bond, J. (2001) 'The media and the movement: Looking back from the southern front'. In B. Ward (ed.), Media, Culture, and the Modern African American Freedom Struggle. Gainesville: University of Florida Press, 16-40.

Branch, T. (1988) Parting the Waters: America in the King years, 1954-1963. New York: Simon and Schuster.

Brown, A. and Brown, K. (2010) 'Strange fruit indeed: Interrogating contemporary textbook representations of racial violence toward African Americans'. Teachers College Record, 112 (1), 31-67. Accessed 14 July 2021. www.tcrecord.org/Content. asp?Contentld=15592.

Brown, S.D. and Hughes, R.L. (2018) '"It's not something we thought about": Teachers' perception of historiography and narratives'. Social Studies Research and Practice, 13 (1), 16-30. https://doi.org/10.1108/SSRP-09-2017-0054.

Carson, C. (1981) In Struggle: SNCC and the black awakening of the 1960s. Cambridge, MA: Harvard University Press.

Carter, D. (1996) From George Wallace to Newt Gingrich: Race in the conservative counterrevolution, 1963-1995. Baton Rouge: Louisiana State University Press.

Chafe, W. (1980) Civilities and Civil Rights: Greensboro, North Carolina and the black struggle for freedom. New York: Oxford University Press.

Crawford, V., Rouse, J. and Woods, B. (1990) Women in the Civil Rights Movement: Trailblazers and torchbearers, 1941-1965. Brooklyn, NY: Carlson Publishing.

Daynes, G. (1997) Making Villains, Making Heroes: Joseph R. McCarthy, Martin Luther King, Jr., and the politics of American memory. New York: Garland.

Dittmer, J. (1995) Local People: The struggle for civil rights in Mississippi. Urbana: University of Illinois Press.

Drake, F. and Nelson, R. (2009) Engagement in Teaching History: Theory and practices for middle and secondary teachers. 2nd ed. Upper Saddle River, NJ: Pearson. 
Dudziak, M. (2000) Cold War Civil Rights: Race and the image of American democracy. Princeton, NJ: Princeton University Press.

Epstein, T. (2008) Interpreting National History: Race, identity, and pedagogy in classrooms and communities. New York: Routledge.

Fairclough. A. (1990) 'Historians and the civil rights movement'. Journal of American Studies, 24 (3), 387-98. https://doi.org/10.1017/S0021875800033697.

Foner, E. (1999) The Story of American Freedom. New York: W.W. Norton \& Company.

Formisano, R. (1991) Boston Against Busing: Race, class, and ethnicity in the 1960s and 1970s. Chapel Hill: University of North Carolina Press.

Frost. J. (2009) 'Teaching the Civil Rights Movement in New Zealand'. Australasian Journal of American Studies, 28, 49-64. https://www.jstor.org/stable/41054147.

Gaines, K. (2002) 'Historiography and the struggle for black equality since 1945'. In J. Agnew and R. Rosenzweig (eds), A Companion to Post-1945 America. Malden, MA: Blackwell, 211-34.

Garrow, D. (1986) Bearing the Cross: Martin Luther King and the Southern Christian Leadership Conference. New York: William Morrow.

Grever, M. and Van der Vlies, T. (2017) 'Why national narratives are perpetuated: Promising reorientations in history textbook research'. London Review of Education, 15 (2), 205-301. https://doi.org/10.18546/LRE.15.2.11

Hall, J.D. (2005) 'The long civil rights movement and the political uses of the past'. The Journal of American History, 91 (4), 1233-63. https://doi.org/10.2307/3660172.

Harris, L.M. and Bain, R.B. (2011) 'Pedagogical content knowledge for world history teachers: What is it? How might prospective teachers develop it?'. The Social Studies, 102 (1), 9-17. https://doi.org/10.1080/00377996.2011.532724.

Heath, D. (2018) 'British empire is still being whitewashed by the school curriculum historian on why this must change'. The Conversation, 2 November. Accessed 2 July 2019. https://theconversation.com/british-empire-is-still-being-whitewashed-by-the-school-curriculumhistorian-on-why-this-must-change-105250.

Hofstadter, R. (1955) The Age of Reform. New York: Vintage.

Jeffries, H. (2009) Bloody Lowndes: Civil rights and Black Power in Alabama's Black Belt. New York: New York University Press.

Joseph, P. (2006) Waiting 'Til the Midnight Hour: A narrative history of black power in America. New York: Henry Holt and Company.

Kelly, R. (1994) Hammer and Hoe: Alabama communists during the Great Depression. Chapel Hill: University of North Carolina Press.

Kousser, J. (1999) Colorblind Injustice: Minority voting rights and the undoing of the Second Reconstruction. Chapel Hill: University of North Carolina Press.

Kruse, K. (2005) White Flight: Atlanta and the making of modern conservatism. Princeton, NJ: Princeton University Press.

Lapsansky-Werner, E.J., Levy, P.B., Roberts, R. and Taylor, A. (2008) United States History: Reconstruction to the present. Upper Saddle River, NJ: Prentice Hall.

Laurent, S. and Wilson, W.J. (2018) King and the Other America: The poor people's campaign and the quest for economic equality. Oakland: University of California Press.

Lawson, S. (1991) 'Freedom then, freedom now: The historiography of the civil rights movement'. American Historical Review, 96 (2), 456-71. https://doi.org/10.2307/2163219.

Lawson, S. (2015) Running for Freedom: Civil rights and black politics in America since 1941. 4th ed. Chichester: Wiley Blackwell.

Lesh, B. (2011) 'Why Won't You Just Tell Us the Answer?': Teaching historical thinking in Grades 7-12. Portsmouth, NH: Stenhouse.

Levstik, L. (2000) 'Articulating the silences: Teachers' and adolescents' conceptions of historical significance'. In P. Stearns, P. Seixas and S. Wineburg (eds), Knowing, Teaching, and Learning History: National and international perspectives. New York: New York University Press, 284-305.

Lewis, J., Aydin A. and Powell N. (2013) March: Book one. Marietta, GA: Top Shelf Productions.

Library of Congress (n.d.) 'Teaching With Primary Sources partner program'. Accessed 14 January 2021. www.loc.gov/programs/teachers/about-this-program/teaching-with-primary-sourcespartner-program/.

Loewen, J. (2018) Lies My Teacher Told Me: Everything your American history textbook got wrong. New York: The New Press.

Matusow, A. (1984) The Unraveling of America: A history of liberalism in the 1960s. New York: Harper and Row. 
Miles, M.B. and Huberman, A.M. (1994) An Expanded Sourcebook: Qualitative data analysis. Thousand Oaks, CA: Sage.

Mohamud, A. and Whitburn, R. (2016) Doing Justice to History: Transforming black history in secondary schools. London: UCL Institute of Education Press.

Moncrieffe, M. (2020) 'Black Lives Matter in education, curriculum, teaching, and learning'. In M. Moncrieffe, Y. Asare and R. Dunford (eds), Decolonising the Curriculum: Teaching and learning about race equality. Brighton: University of Brighton Press, 7-8.

Moncrieffe, M. and Harris, R. (2020) 'Repositioning curriculum teaching and learning through BlackBritish history'. Research Intelligence, 144, 14-15. Accessed 14 July 2021. https://cris.brighton. ac.uk/ws/portalfiles/portal/15526198/Repositioning_curriculum_teaching_and_learning_ through_Black_British_history.pdf.

Monte-Sano, C. and Budano, C. (2013) 'Developing and enacting pedagogical content knowledge for teaching history: An exploration of two novice teachers' growth over three years'. Journal of the Learning Sciences, 22 (2), 171-211. https://doi.org/10.1080/10508406.2012.742016.

Monte-Sano, C., De La Paz, S. and Felton, M. (2014) Reading, Thinking, and Writing About History: Teaching argument writing to diverse learners in the Common Core classroom, Grades 6-12. New York: Teachers College Press.

Morris, A. (1984) The Origins of the Civil Rights Movement: Black communities organizing for change. New York: Free Press.

NCSS (National Council for the Social Studies) (2013) College, Career, and Civic Life (C3) Framework for Social Studies State Standards: Guidance for enhancing the rigor of K-12 Civics, Economics, Geography, and History. Silver Spring, MD: NCSS.

New York Times Magazine (2019) 'The 1619 Project'. Accessed 25 July 2021. www.nytimes.com/ interactive/2019/08/14/magazine/1619-america-slavery.html.

Nokes, J. (2019) Teaching History, Learning Citizenship: Tools for civic engagement. New York: Teachers College Press.

Oates, S. (1982) Let the Trumpet Sound: The life of Martin Luther King, Jr. New York: Harper and Row.

Payne, C. (1995) I've Got the Light of Freedom: The organizing tradition and the Mississippi struggle. Berkeley: University of California Press.

Pinckney, D. (2015) 'Some different ways at looking at Selma'. New York Review of Books, 19 February. Accessed 14 July 2021. www.nybooks.com/articles/2015/02/19/some-different-wayslooking-selma/.

Raphael, R. (2004) Founding Myths: Stories that hide our patriotic past. New York: New Press.

Romano, R. and Raiford, L. (eds) (2006) The Civil Rights Movement in American Memory. Athens: University of Georgia Press.

Rosenzweig, R. (2000) 'How Americans use and think about the past: Implications from a national survey for the teaching of history'. In P. Stearns, P. Seixas and S. Wineburg (eds), Knowing, Teaching, and Learning History. New York: New York University Press, 262-83.

Rustin, B. (1971) Down the Line: The collected writings of Bayard Rustin. Chicago: Quadrangle Books.

Salinas, C. and Blevins, B. (2014) 'Critical historical inquiry: How might pre-service teachers confront master historical narratives?'. Social Studies Research and Practice, 9 (3), 35-50. Accessed 14 July 2021. www.socstrpr.org/wp-content/uploads/2015/01/MS06592Salinas.pdf.

Sanchez, A. (2016) 'What happened to the civil rights movement after 1965? Don't ask your textbook'. Zinn Education Project, 15 June. Accessed 14 July 2021. www.commondreams.org/ views/2016/06/15/what-happened-civil-rights-movement-after-1965-dont-ask-your-textbook.

Seixas, P. (ed.) (2004) Theorizing Historical Consciousness. Toronto: University of Toronto Press.

Seixas, P. (2007) 'Who needs a canon?' In M. Grever and S. Stuurman (eds), Beyond the Canon: History for the twenty-first century. Basingstoke: Palgrave Macmillan, 19-30.

Seixas, P. and Morton, T. (2013) The Big Six Historical Thinking Concepts. Toronto: Nelson Education.

Self, R. (2005) American Babylon: Race and the struggle for postwar Oakland. Princeton, NJ: Princeton University Press.

Shulman, L.S. (1986) 'Those who understand: Knowledge growth in teaching'. Educational Researcher, 15 (2), 4-14. https://doi.org/10.3102\%2F0013189X015002004.

Southern Poverty Law Center (n.d.) 'Teaching hard history: American slavery'. Accessed 21 October 2020. www.tolerance.org/frameworks/teaching-hard-history/american-slavery.

Stanford History Education Group (n.d.) 'Reading like a historian'. Accessed 25 July 2021.

https://sheg.stanford.edu/history-lessons. 
Sugrue, T. (1996) The Origins of the Urban Crisis: Race and inequality in postwar Detroit. Princeton: Princeton University Press.

Sullivan, P. (1996) Days of Hope: Race and democracy in the New Deal. Chapel Hill: University of North Carolina Press.

Swalwell, K., Pellegrino, A.M. and View, J.L. (2015) 'Teachers' curricular choices when teaching histories of oppressed people: Capturing the U.S. Civil Rights Movement'. Journal of Social Studies Research, 39 (2), 79-94. https://doi.org/10.1016/j.jssr.2014.11.003.

Takaki, R. (1993) A Different Mirror: A history of multicultural America. Boston: Little, Brown and Company.

The College Board (2019) AP United States History: Free-response questions. Accessed 25 July 2021. https://apstudents.collegeboard.org/ap/pdf/ap19-frq-us-history.pdf.

Theoharis, J. (2018) A More Beautiful and Terrible Story: The uses and misuses of civil rights history. Boston, MA: Beacon Press.

Thornton, J. (2002) Dividing Lines: Municipal politics and the struggle for civil rights in Montgomery, Birmingham, and Selma. Tuscaloosa: University of Alabama Press.

Tyson, T. (1999) Radio Free Dixie: Robert F. Williams and the roots of black power. Chapel Hill: University of North Carolina Press.

Vanhulle, B. (2009) 'The path of history: Narrative analysis of history textbooks - a case study of Belgian history textbooks (1945-2004)'. History of Education: Journal of the History of Education Society, 38 (2), 263-82. https://doi.org/10.1080/00467600701827837.

VanSledright, B.A. (2008) 'Narratives of nation-state, historical knowledge, and school history education'. Review of Research in Education, 32 (1), 109-46. https://doi.org/10.3102\%2F009173 2X07311065

VanSledright, B.A. (2011) The Challenge of Rethinking History Education: On practices, theories, and policy. New York: Routledge.

Von Eschen, P. (1997) Race Against Empire: Black Americans and anticolonialism, 1937-1957. Ithaca, NY: Cornell University Press.

Walker, J. (2001) 'A media-made movement? Black violence and nonviolence in the historiography of the civil rights movement'. In B. Ward (ed.), Media, Culture, and the Modern African American Freedom Struggle. Gainesville: University of Florida Press, 41-66.

Ward, B. and Hunt, M. (2020) 'Study shows UK school textbooks teach a highly simplified version of US civil rights movement'. The Conversation, 4 September. Accessed 15 November 2020. https://theconversation.com/study-shows-uk-school-textbooks-teach-a-highly-simplified-versionof-us-civil-rights-movement-144319.

Wertsch, J.V. (1998) Mind as Action. New York: Oxford University Press.

Wertsch, J.V. (2008) 'Collective memory and narrative templates'. Social Research: An international quarterly, 75 (1), 133-56. Accessed 14 July 2021. https://muse.jhu.edu/article/527987/pdf.

Wineburg, S. and Monte-Sano, C. (2008) '"Famous Americans": The changing pantheon of American heroes'. The Journal of American History, 94 (4), 1186-202. https://doi.org/10.2307/25095326.

Wineburg, S. and Wilson, S. (2001) 'Peering at history through different lenses: The role of disciplinary perspectives in teaching history'. In S. Wineburg (ed.), Historical Thinking and Other Unnatural Acts: Charting the future of teaching the past. Philadelphia: Temple University Press, 139-54.

Wineburg, S., Martin, D. and Monte-Sano, C. (2011) Reading Like a Historian: Teaching literacy in middle and high school history classrooms. New York: Teachers College Press.

Wright, G. (2013) Sharing the Prize: The economics of the civil rights revolution in the American South. Cambridge, MA: Harvard University Press.

Yin, R.K. (2003) Case Study Research: Design and methods. Thousand Oaks, CA: Sage. 